\title{
Life-history strategies associated to reproduction of three Hyphessobrycon species (Characidae) in lentic environments of upper Paraná River basin
}

Estratégias de história de vida associadas à reprodução de três espécies de Hyphessobrycon (Characidae) em ambientes lênticos da bacia do alto rio Paraná

Cristina da Silva Gonçalves ${ }^{1}$, Ursulla Pereira Souza ${ }^{2}$, Fabio Cop Ferreira ${ }^{3}$, Alexandre Peressin ${ }^{4}$ and Francisco Manoel de Souza Braga

${ }^{1}$ Laboratório de Ictiologia, Universidade Estadual Paulista "Júlio de Mesquita Filho" - UNESP, CEP 15054-000, São José do Rio Preto, SP, Brazil

e-mail: cristina.silva.goncalves@gmail.com

${ }^{2}$ Programa de Pós-graduação em Sustentabilidade de Ecossistemas Costeiros e Marinhos, Universidade Santa Cecília - UNISANTA, Rua Oswaldo Cruz, 277, Boqueirão, CEP 11045-907, Santos, SP, Brazil

${ }^{3}$ Departamento de Ecologia, Universidade Estadual Paulista “Júlio de Mesquita Filho" - UNESP, CEP 13506-900, Rio Claro, SP, Brazil

e-mail: upsouza@gmail.com; fabiocferreira@gmail.com

${ }^{4}$ Programa de Pós-graduação em Diversidade Biológica e Conservação,

Universidade Federal de São Carlos - UFSCar, CEP 18052-780, Sorocaba, SP, Brazil e-mail: alex_peressin@yahoo.com.br

${ }^{5}$ Departamento de Zoologia, Universidade Estadual Paulista “Júlio de Mesquita Filho" - UNESP, CEP 13506-900, Rio Claro, SP, Brazil e-mail: fmsbraga@rc.unesp.br

\begin{abstract}
Aim: Life-history strategies in fish include essential parameters related to offspring survivorship, fecundity and time of reproduction, which represent adaptive traits that enable a species to deal with spatial and temporal variability of abiotic conditions. This study aimed to compare reproductive traits associated to life-history theory for three Hyphessobrycon species from two lentic environments (four natural oxbow lakes and a manmade reservoir) of Mogi Guaçu River, upper Paraná River basin. Methods: Specimens were collected with four minnow traps between August 2005 and July 2006 to cover dry and wet seasons (three samples in each season, and three samples in each environment). Results: Reproductive strategy of $H$. bifasciatus and $H$. eques, which predominated in the oxbow lakes, differed from $H$. anisitsi in the reservoir. Hyphessobrycon bifasciatus and $H$. eques were single spawners with lower fecundity and size at sexual maturity, but invested more in number of eggs per body gram, while $H$. anisitsi was a multiple spawner species with higher fecundity, larger size at sexual maturity and body size. Conclusions: In seasonal environments, single spawners are synchronized with the floods to maximize juvenile survivorship, while reservoirs harbors multiple spawners' fish due to the reduced fluctuation between high and low floods resulting from dam operation. Therefore, the seasonal condition in the oxbow lakes due to the flood pulse favored single spawners' tactic, as showed by $H$. bifasciatus and $H$. eques. In contrast, the multiple spawning of $H$. anisitsi seems to be related to the more stable environmental condition throughout the year provided by the dam. Life-histories reported herein to Hyphessobrycon species must be common to other characid fishes inhabiting similar environments.
\end{abstract}

Keywords: tetra fishes, spawning, fecundity, body condition.

Resumo: Objetivo: Em peixes, as estratégias de história de vida incluem parâmetros relacionados com a sobrevivência da prole, fecundidade e período reprodutivo, e representam características adaptativas que permitem uma espécie lidar com a variabilidade espacial e temporal das condiçóes abióticas. O objetivo deste estudo foi comparar as características reprodutivas associadas à teoria da história de vida de três espécies de Hyphessobrycon em dois ambientes lênticos (quatro lagoas marginais naturais e uma represa artificial) do rio Mogi Guaçu, bacia do alto rio Paraná. Métodos: Os exemplares foram coletados com quatro armadilhas do tipo covo entre Agosto de 2005 e Julho de 2006 para abranger as estações seca e chuvosa (três amostras em cada estação e três amostras em cada ambiente). Resultados: A estratégia reprodutiva de $H$. bifasciatus e $H$. eques, que ocorreram principalmente nas lagoas marginais, diferiu de $H$. anisitsi no reservatório. Hyphessobrycon bifasciatus e $H$. eques foram classificados como desovadores 
únicos, com fecundidade e tamanho de maturação gonadal menor, mas investiram mais em número de ovócitos por peso corpóreo, enquanto $H$. anisitsi foi classificado como desovador múltiplo, com fecundidade, tamanho de maturação gonadal e corpóreo maior. Conclusóes: Em ambientes sazonais, os desovadores totais estão sincronizados com o período de inundaçáo para maximizar a sobrevivência da prole, enquanto reservatórios abrigam desovadores múltiplos, devido à flutuação reduzida entre inundaçóes resultante da operaçáo da represa. Dessa forma, a condição sazonal das lagoas marginais devido ao pulso de inundação, favorece a tática reprodutiva dos desovadores totais, como apresentado por $H$. bifasciatus e $H$. eques. Ao contrário, a desova múltipla de $H$. anisitsi parece estar relacionada com a condição ambiental mais estável do ambiente ao longo do ano devido ao represamento. As histórias de vida registradas aqui para as espécies de Hyphessobrycon devem ser comuns para outras espécies de caracídeos que habitam ambientes similares.

Palavras-chave: caracídeos, desova, fecundidade, condição corpórea.

\section{Introduction}

The Neotropical region has the most diversified freshwater fish fauna in the world (Lévêque et al., 2008) accompanied by an important diversity of life-history patterns (Winemiller, 1989). Lifehistory strategies in fish include essential parameters related to offspring survivorship, fecundity and time of reproduction, which represent adaptive traits that enable a species to deal with spatial and temporal variability of abiotic conditions, food availability and predation pressure (Winemiller, 1989, 1992, 2005; Winemiller and Rose, 1992). A current life-history model for fish (Winemiller, 1989; Winemiller and Rose, 1992) describes a "triangular pattern" in which three endpoints classifies the species as "equilibrium", "opportunistic", or "seasonal” strategists, according to fishes' mortality, generation time, fecundity, and other factors. Vila-Gispert et al. (2002) showed that basic lifehistories patterns of fishes from North and South America, Europe, and Atlantic and Pacific oceans are convergent, i.e., fishes exhibit similar responses to equivalent selection pressures, reinforcing that the three endpoints model represent a general pattern in nature. Reproductive traits can be related to some environmental constraints (Wootton, 1992), allowing a better understanding of the responses of the species to natural and anthropogenic environmental changes. Such knowledge may also facilitate management decisions regarding the mitigation of environmental impacts on aquatic systems (Olden and Kennard, 2010; Winemiller, 2005).

Rivers damming is one of the most impacting actions upon lotic ecosystems across the world. Damming disrupts the longitudinal continuum of physical and biological features of the river basin (Dugan et al., 2010; Welcomme et al., 2006), and creates a new environment with different hydrologic condition, deeply modifying the original fish communities (Agostinho et al., 2008). The hydrological variability may act as a selective filter for fish species in function of its life-histories traits (i.e. reproductive strategies) (Tedesco et al., 2008). In this sense, both floodplain dynamic and habitat heterogeneity are important factors influencing fish reproduction in river-floodplain systems (Zeug and Winemiller, 2007). Therefore, damming a river stretch can influence a whole set of life-history traits of fishes, especially those related to reproduction (Agostinho et al., 1999).

The genus Hyphessobrycon Durbin includes 97 valid species distributed from southern Mexico to the La Plata River in Argentina, and is by far one of the most speciose genera within the Characidae (Lima and Moreira, 2003). The diversity of this genus provides an opportunity to investigate life-history variation among related species across a wide variety of environmental conditions. Hyphessobrycon anisitsi (Eigenmann, 1907), $H$. bifasciatus Ellis, 1911 and H. eques (Steindachner, 1882) are originally found in Paraná and Uruguay River basins $(H$. anisitsi), rivers of eastern Brazil and upper Paraná (H. bifasciatus), and in Amazon and Paraguay basins (H. eques). Actually, H. eques are widespread through the upper Paraná River basin and rivers of eastern Brazil as a result of introductions (Buckup et al., 2007). These smallbodied sized species are quite abundant in the Mogi Guaçu River, in which they have been recorded in different kinds of environments such as streams, rivers, oxbow lakes and reservoir (Meschiatti and Arcifa, 2009). Gonçalves and Braga (2008) verified that these Hyphessobrycon species are among the most abundant fishes in lentic environments (oxbow lakes and a reservoir) in Mogi Guaçu River. 
In the present study, life-history patterns of $H$. anisitsi, $H$. bifasciatus and $H$. eques were investigated based on fecundity, spawning type, body size, body condition, and size at sexual maturity, in four oxbow lakes and in the reservoir of a Small Hydroelectric Power plant (SHP) of the Mogi Guaçu River (São Paulo State, southeast Brazil), in order to compare their reproductive strategies in these lentic environments.

\section{Material and Methods}

\subsection{Study area}

The Mogi Guaçu River has an extension of 473 $\mathrm{km}$, and rises in the Mantiqueira mountain range at 1,650 m (Minas Gerais State), southeast Brazil. The four oxbow lakes studied (Pedra, Catingueiro, Barrinha and Fundão) are located at Mogi Guaçu Ecological Station (Mogi Guaçu municipality, São Paulo State), a conservation unit with 980.71 ha, also known as Campininha farm $\left(22^{\circ} 16^{\prime} \mathrm{S}\right.$ and $\left.47^{\circ} 12^{\prime} \mathrm{W}\right)$. These are small permanent oxbow lakes seasonally connected to Mogi Guaçu River according with the flood pulse intensity during summer months (wet season) (C. S. Gonçalves personal observation). Their physical, chemical and structural features are presented in Table 1, which are quite similar to other oxbows of the upper Paraná River floodplain (Agostinho and Júlio Junior, 1999). The Mogi Guaçu Reservoir (22 21' S and 46 $51^{\circ}$ $\mathrm{W})$ is a run-of-the-river impoundment and was formed in 1994 by the damming of the Mogi Guaçu and Peixe rivers in order to supply the neighboring municipalities and generate 7.2 MW of electric power. The water residence time is $72 \mathrm{~h}$. The studied oxbows are located in the upper reach of Mogi
Guaçu River and 43 km downstream Mogi Guaçu Reservoir (Gonçalves and Braga, 2008).

The damming regulates the natural river flow, and thus the oxbow lakes may eventually suffer the effects of this control. Despite this, the oxbow lakes studied herein can still be influenced by the flood pulse of the Mogi Guaçu River during rainfall peak in the summer; only Barrinha was not affected by overflow during the study period (C. S. Gonçalves personal observation). The composition of fish assemblage of these oxbow lakes and reservoir was described by Gonçalves and Braga (2008); other characteristics of the studied area are presented in Table 1.

\subsection{Sampling methods and data collection}

Samples were taken in oxbow and reservoir between August 2005 and July 2006 to cover the dry and the wet seasons, i.e., three samples in each season, and three samples in each environment, totaling twelve samples. Specimens were collected with four baited minnow traps (approximately $60 \mathrm{~cm}$ long and $20 \mathrm{~cm}$ wide, without meshes), using dog food as bait. The traps were set during the afternoon, near the marginal vegetation, and collected in the following morning after $-18 \mathrm{~h}$ exposure (see Gonçalves and Braga, 2008 for detailed sampling procedure). Dry and wet periods in the study area was determined according to methodology proposed by Walter and Lieth (1960), using the average of 30 years of rainfall and air temperature, and data provided by the meteorological station (D4-100) located on the Campininha farm. The dry period corresponded from April to September, and the wet period from October to March.

Table 1. Characteristics of the sampled sites (Catingueiro, Barrinha, Pedra and Fundão oxbow lakes, and reservoir) at Mogi Guaçu River, southeast Brazil. Adapted from Gonçalves and Braga (2008).

\begin{tabular}{|c|c|c|c|c|c|}
\hline & Pedra & Catingueiro & Barrinha & Fundão & Reservoir \\
\hline $\mathrm{pH}($ mean $\pm \mathrm{sd})$ & $5.5 \pm 0.2$ & $5.2 \pm 0.3$ & $5.6 \pm 0.1$ & $5.8 \pm 0.1$ & $6.6 \pm 0.2$ \\
\hline Dissolved oxygen (mg.L-1 $)$ & $1.4(1.2-1.5)$ & $0.6(0.4-0.7)$ & $7.0(6.4-7.2)$ & $2.0(2.0-2.2)$ & $7.0(5.3-8.8)$ \\
\hline Surface area & - & - & - & - & $5.73 \mathrm{~km}^{2}$ \\
\hline Volume & - & - & - & - & $32.89 \times 10^{6} \mathrm{~m}^{3}$ \\
\hline Maximum depth (m) & 3.0 & 2.5 & 2.3 & 3.0 & $8.5^{*}$ \\
\hline Bottom type & mud and silt & - & mud and silt & mud and silt & mud and silt \\
\hline Aquatic vegetation & scarce & abundant & $\begin{array}{c}\text { abundant and } \\
\text { diverse }\end{array}$ & abundant & $\begin{array}{c}\text { abundant and } \\
\text { diverse }\end{array}$ \\
\hline Surrounding vegetation & \multicolumn{4}{|c|}{ "Seasonal Semideciduous" forest remnants } & $\begin{array}{c}\text { sugar cane and } \\
\text { pasture }\end{array}$ \\
\hline Connection with the river & seasonal & seasonal & isolated & seasonal & - \\
\hline Distance from the river (m) & 60 & 85 & 150 & 80 & - \\
\hline
\end{tabular}

*Brandimarte et al. (2008). 
Fishes were fixed in 10\% formalin and later conserved in $70 \%$ ethanol. Voucher specimens are deposited in the fish collection of Departamento de Zoologia e Botânica, UNESP - São José do Rio Preto (DZSJRP 012378, DZSJRP 012384, DZSJRP 012385).

In the laboratory, we obtained the standard length $(\mathrm{mm})$, total weight $(\mathrm{g})$, and sex of each specimen. Gonadal maturation stages were defined macroscopically according to oocyte's appearance, color, vascularization and transparency of the gonads, in the following categories: A (immature), $\mathrm{B}$ (maturing), C (mature) and D (spent) (cf. Vazzoler, 1996). To assess fecundity, only mature ovaries characterized by the presence of vitellogenic oocytes, i.e., stage $\mathrm{C}$, were removed from the visceral cavity, weighted and kept in Gilson's solution until complete detachment of oocytes from epithelium and ovarian follicles.

\subsection{Data analyses}

Total fecundity (calculated for both ovaries) was estimated using the volumetric method (Vazzoler, 1996). The total count of vitellogenic oocytes, i.e., perinucleolar oocytes were not considered, was performed under a stereomicroscope (40x magnification); 100 of these oocytes were randomly selected to be measured with an ocular micrometer (10x magnification). The spawning type (single or multiple) was determined according to the frequency distribution of oocytes by diameter classes. Single spawners are species that mature and spawn only one batch of oocytes per spawning season, and multiple spawners release its oocytes in more than one batch during the spawning season (Godinho et al., 2010).

An Analysis of Variance (ANOVA) followed by $a$ posteriori Tukey test was used to compare the mean fecundity (log transformed) among Hyphessobrycon species. Simple linear regressions were used to verify the dependence of fecundity on total weight for each species, following the model: $\operatorname{Ln}(F)=a+b \operatorname{Ln}$ $(W)+e$, were $F$ is the fecundity estimated for the mature females, $W_{t}$ is the total weight, $e$ is the error (with normal distribution and constant variance), and $a$ and $b$ are the model parameters representing the intercept and the slope, respectively. The slope $b$ was compared among the three species using an Analysis of Covariance model (ANCOVA) (Zar, 2010).

The average length between sexes for each species was compared using t-tests (Zar, 2010). The body condition was assessed to identify differences in the relationship between length and weight of the three species. It was evaluated by ANCOVA models in order to determine whether the total weight (dependent variable) varied among species or sexes (factors) when controlling for the effect of standard length (covariate) (Cetra, 2005), according to the model: $\log \left(W_{i j}\right)=\mu+S_{i}+\beta_{i}\left(\log L_{i j}-\log L_{i}\right)+\varepsilon_{i j}$, where $W_{i j}$ is the total weight of the individual $j$ in sex $i$ (male or female), $\mu$ is the population mean, $S_{i}$ is the effect of sex $i, L_{i j}$ is the standard length of individual $j$ in sex $i, L_{i}$ is the mean standard length of sex $i$ and $\varepsilon_{i j}$ is the random error associated to individual $j$ in sex $i$.

Size at first sexual maturity was calculated by means of a logistic regression according to the model: $M A T=\frac{\mathrm{e}^{\mathrm{a}+\mathrm{bL}}}{1+\mathrm{e}^{\mathrm{a}+\mathrm{bL}}}$, were $M A T$ is the response variable ( 0 for immature and 1 for mature fishes), $L$ is the standard length, and $a$ and $b$ parameters of the equation. After adjusting this equation for each species, the size at first sexual maturity (i.e. the length at which $50 \%$ of the fishes are expected to be mature) was calculated by substituting $M A T$ by 0.5 and finding the corresponding $L$.

All statistical analyses were performed in $\mathrm{R}$ software, version 3.0.1 (R Development Core Team, 2013), considering the significance level at 5\%.

\section{Results}

A total of 552 specimens were collected (Table 2). Hyphessobrycon bifasciatus occurred only in oxbow lakes (112 specimens). Hyphessobrycon eques predominated in oxbow lakes (354 specimens) but was also captured in the reservoir (25 specimens), while $H$. anisitsi predominated in the reservoir $(58$ specimens) but also occurred in oxbow lakes (3 specimens).

Fecundity was estimated from the analysis of 32, 111 and 17 mature ovaries of $H$. bifasciatus, $H$. eques and $H$. anisitsi, respectively, and ranged from 151 to 1,017 (mean $=482 \pm 221 \mathrm{sd}), 137$ to $848(486 \pm 159)$, and 298 to $2,040(931 \pm 521)$ oocytes for each species (Table 2). The distribution of oocytes diameters (Figure 1) showed only one batch of mature oocytes for $H$. bifasciatus and $H$. eques, which ranged from 216 to $360 \mu \mathrm{m}$ and 600 to $768 \mu \mathrm{m}$, respectively, suggesting that they are single spawners. Hyphessobrycon anisitsi evidenced two batches; one composed by several small oocytes (between 144-432 $\mu \mathrm{m}$ ) that are still under development, and another batch with larger oocytes (between $504-816 \mu \mathrm{m}$ ) in advanced stage of 
Table 2. Abundance patterns and life-history traits of Hyphessobrycon species. $\mathrm{SL}_{2}, \mathrm{SL}_{\circ}$ : standard length (mm) of males and females, respectively. $\mathrm{LW}_{\text {regression }}$ : parameters of the linear regressions between Ln (Length) and Ln (Weight). $\mathrm{FW}_{\text {regression }}$ : parameters of the linear regressions between Ln (Fecundity) and Ln (Weight). se: standard errors.

\begin{tabular}{|c|c|c|c|c|c|c|}
\hline \multirow[t]{2}{*}{ Occurrence } & \multicolumn{2}{|c|}{ H. bifasciatus } & \multicolumn{2}{|c|}{ H. eques } & \multicolumn{2}{|c|}{ H. anisitsi } \\
\hline & Dry & Wet & Dry & Wet & Dry & Wet \\
\hline Pedra & 46 & 1 & - & - & - & - \\
\hline Catingueiro & 19 & 31 & - & - & - & - \\
\hline Barrinha & 12 & 3 & 121 & 215 & 1 & 1 \\
\hline Fundão & - & - & - & 18 & - & 1 \\
\hline Reservoir & - & - & 1 & 24 & 1 & 57 \\
\hline \multicolumn{7}{|l|}{ Life-history traits } \\
\hline Mean $\mathrm{SL}_{\hat{\delta}}(\min -\max )$ & \multicolumn{2}{|c|}{$31(20-42)$} & \multicolumn{2}{|c|}{$29(20-37)$} & \multicolumn{2}{|c|}{$37(26-46)$} \\
\hline Mean SL ${ }_{q}$ (min-max) & \multicolumn{2}{|c|}{$30(19-44)$} & \multicolumn{2}{|c|}{$30(24-37)$} & \multicolumn{2}{|c|}{$42(32-49)$} \\
\hline \multirow[t]{2}{*}{$\mathrm{LW}_{\text {regression }}(\mathrm{se})$} & \multicolumn{2}{|c|}{$a=-10.14(0.30)$} & \multicolumn{2}{|c|}{$a=-9.27(0.23)$} & \multicolumn{2}{|c|}{$a=-11.73(0.31)$} \\
\hline & \multicolumn{2}{|c|}{$\begin{array}{c}\mathrm{b}=2.85(0.09) \\
\mathrm{n}=92\end{array}$} & \multicolumn{2}{|c|}{$\begin{array}{c}\mathrm{b}=2.61(0.07) \\
\mathrm{n}=360\end{array}$} & \multicolumn{2}{|c|}{$\begin{array}{c}\mathrm{b}=3.27(0.08) \\
\mathrm{n}=49\end{array}$} \\
\hline Mean fecundity (min-max) ${ }^{*}$ & \multicolumn{2}{|c|}{$482(151-1,017)$} & \multicolumn{2}{|c|}{$486(137-848)$} & \multicolumn{2}{|c|}{$931(298-2,040)$} \\
\hline \multirow[t]{2}{*}{$\mathrm{FW}_{\text {regression }}(\mathrm{se})$} & \multicolumn{2}{|c|}{$a=6.05(0.09)$} & \multicolumn{2}{|c|}{$a=6.49(0.07)$} & \multicolumn{2}{|c|}{$a=6.10(0.09)$} \\
\hline & \multicolumn{2}{|c|}{$\begin{array}{c}b=0.26(0.17) \\
n=35 \\
r=0.25\end{array}$} & \multicolumn{2}{|c|}{$\begin{array}{c}b=1.00(0.16) \\
n=111 \\
r=0.50\end{array}$} & \multicolumn{2}{|c|}{$\begin{array}{c}b=1.98(0.42) \\
n=17 \\
r=0.91\end{array}$} \\
\hline Spawning type* & \multicolumn{2}{|c|}{ Single } & \multicolumn{2}{|c|}{ Single } & \multicolumn{2}{|c|}{ Multiple } \\
\hline
\end{tabular}

*These parameters were determinate only in oxbow lakes for Hyphessobrycon eques and in the reservoir for $H$. anisitsi.
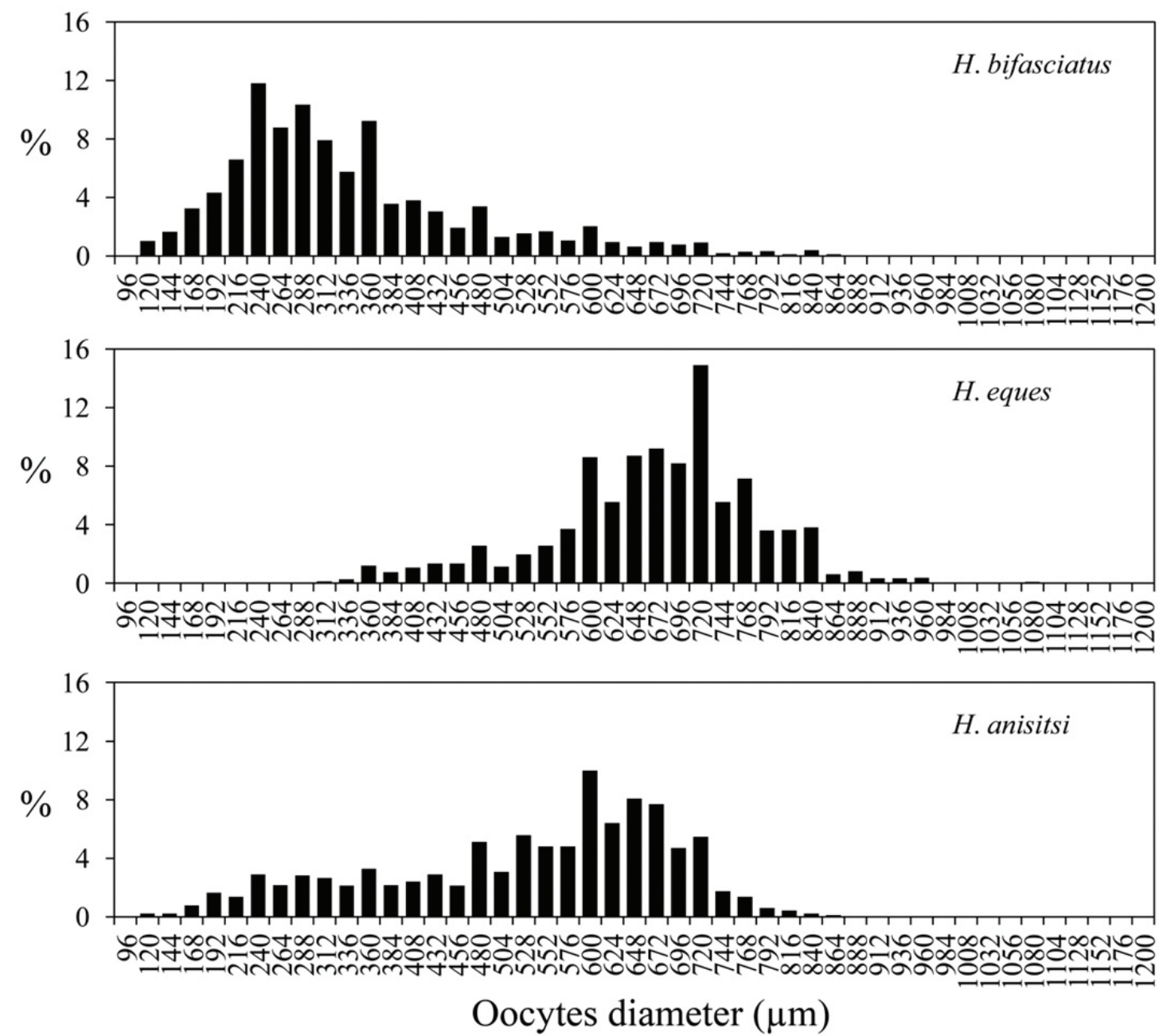

Figure 1. Frequency (\%) of oocytes by diameters classes of Hyphessobrycon species, showing one oocytes batch to $H$. bifasciatus and $H$. eques, and two oocytes batches to $H$. anisitsi. 
development, which indicate a multiple spawning species.

Mature females of $H$. bifasciatus predominated in the dry season (only eight mature females occurred during the wet season). The opposite was recorded for $H$. eques and $H$. anisitsi: mature females predominated during the wet season (four mature females of $H$. eques occurred in the dry season and none for $H$. anisitsi). Mean fecundity was higher for $H$. anisitsi than for $H$. bifasciatus and $H$. eques $\left(\mathrm{F}_{2,160}=12.97, \mathrm{p}<0.001\right)$ and increased with weight for $H$. eques and $H$. anisitsi $(\mathrm{p}<0.001)$, but not for $H$. bifasciatus $(\mathrm{p}=0.148)$ (Table 2, Figure 2) $\left(\right.$ ANCOVA: $\mathrm{F}_{\text {intertaction }}=11.52, \mathrm{df}_{\text {interaction }}=2$, $\left.\mathrm{df}_{\text {residual }}=157, \mathrm{p}<0.001\right)$.

Hyphessobrycon anisitsi had the greatest length range and $H$. eques the lowest (Table 2). Females were on average larger than males in $H$. anisitsi $\left(\mathrm{t}=3.70, \mathrm{df}=47, \mathrm{p}=0.001, \mathrm{n}_{\text {females }}=30, \mathrm{n}\right.$ males $=19)$ and $H$. eques $(\mathrm{t}=3.32$, df $=358$, $\left.\mathrm{p}=0.001, \mathrm{n}_{\text {females }}=198, \mathrm{n}_{\text {males }}=162\right)$, but not in $H$. bifasciatus $(\mathrm{t}=0.33, \mathrm{df}=90, \mathrm{p}=0.738, \mathrm{n}$ females $\left.=50, \mathrm{n}_{\text {males }}=42\right)$. The significant interaction term in the ANCOVA model indicated that the slope of length-weight relationship is not the same for all three species $\left(\mathrm{F}_{\text {interaction }}=6.27, \mathrm{df}_{\text {interaction }}=2\right.$; $\left.\mathrm{df}_{\text {residual }}=489, \mathrm{p}=0.002\right)$. Linear regressions for each species showed a lower and similar relationship for $H$. bifasciatus $(\mathrm{b}=2.85)$ and $H$. eques $(\mathrm{b}=2.61)$ and a greater inclination for $H$. anisitsi $(\mathrm{b}=3.27)$ (Table 2). There was no significant difference in the length-weight slope between sexes for $H$. bifasciatus $(\mathrm{p}=0.273), H$. eques $(\mathrm{p}=0.316)$, or $H$. anisitsi $(\mathrm{p}=0.904)$.

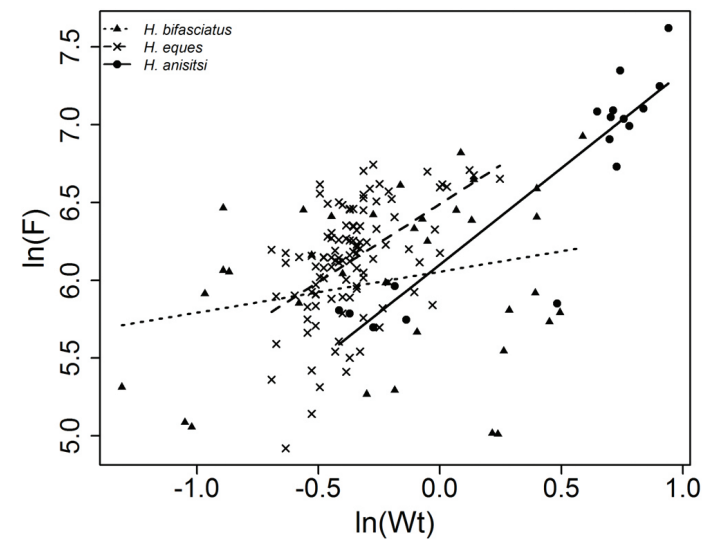

Figure 2. Relationships between fecundity (F), and total weight (W), for Hyphessobrycon bifasciatus, H. eques, and $H$. anisitsi. The parameters of the linear regressions are presented in Table 2.
The size at first sexual maturity was similar for $H$. bifasciatus and $H$. eques $(19.4 \mathrm{~cm}$ and $20.0 \mathrm{~cm}$, respectively), while $H$. anisitsi attained the largest size $(27.8 \mathrm{~cm})$ (Figure 3).

\section{Discussion}

Among the life-history traits, fecundity, oocytes' size, the number of clutches, and the reproductive season possibly affects the reproductive success of a species in a particular environment (Matthews, 1998), and are expected to evolve as an adaptative responses to environmental pressures (Winemiller, 2005). The results obtained herein indicated that the two Hyphessobrycon species that predominated in the oxbow lakes (H. bifasciatus and H. eques) were single spawners (i.e. a single bout of reproduction per year) whereas $H$. anisitsi that predominated in the reservoir was a multiple spawner (i.e. repeated reproductive bouts per year). In seasonal environments, single spawners are synchronized with the floods to maximize the juvenile survivorship (Agostinho and Júlio Junior, 1999), while reservoirs harbors multiple spawners' fish due to the reduced fluctuation between high and low floods resulted from dam regulation (Petesse et al., 2007). Considering that river damming control the riverflow (Agostinho et al., 2008), the studied oxbow lakes herein may eventually suffer the effects of this control since they are located $43 \mathrm{~km}$ downstream reservoir. However, during the study period we observed that the oxbow lakes were influenced by overflow of Mogi Guaçu River all over the rainfall peak in the summer. Therefore, the seasonality of flood imposed to the oxbow lakes may favor single spawners as $H$. bifasciatus and $H$. eques, while the

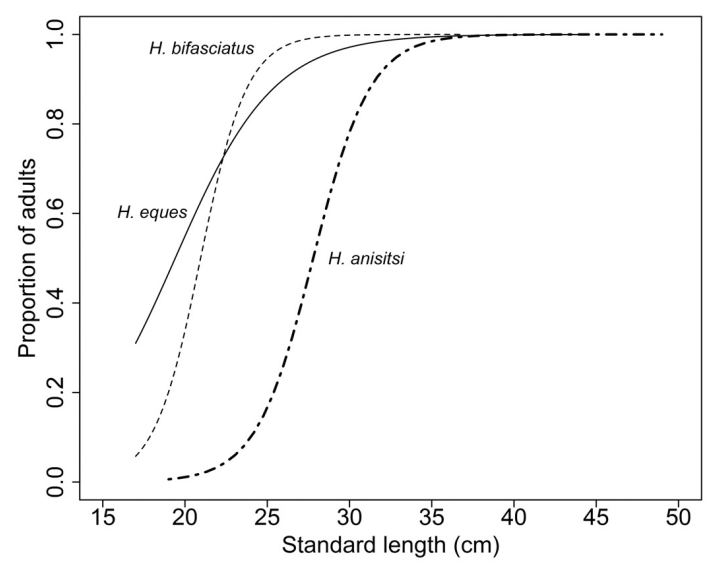

Figure 3. Proportion of adults considering the standard length of Hyphessobrycon bifasciatus, $H$. eques, and $H$. anisitsi. 
more stable hydrologic condition throughout the year provided by the dam support the multiple spawning species as $H$. anisitsi. According to Agostinho and Júlio Junior (1999), several biological processes that occur in the floodplain of the upper Paraná River are dependent on the flooding regime, as evidenced by the adjustment of the biological cycle of several species to river fluctuations. Fishes inhabiting seasonal environments are exposed to periodical fluctuations of environmental parameters of river-floodplain systems (Junk et al., 1989), which are supposed to represent the main selective pressures acting on the biological strategies of the aquatic organisms.

Fecundity, body size, body condition and size at sexual maturity varied among Hyphessobrycon species. The body size differences between sexes and the relationships between fecundity and body weight may be related to the reproductive strategy adopted by fish populations. For instance, the largest body size reached by $H$. eques and $H$. anisitsi females compared to males is a reproductive strategy related to sexual dimorphism (Agostinho and Júlio Junior, 1999). In fish, fecundity depends on the size of coelomic cavity to accommodate mature ovaries (which are bigger than immature ovaries), thus, larger females are more fecund (Wootton, 1992), as evidenced by fecundity-weight relationships to $H$. eques and $H$. anisitsi. For $H$. bifasciatus, body size was not different between males and females, and there was no relationship between female fecundity and body size.

We also verified that mean fecundity was higher for $H$. anisitsi but regression analyses revealed that this was a consequence of the larger body sizes attained by mature females. Conversely, when comparing the fecundity for individuals of the same weight, we verified that the reproductive effort (number of oocytes per gram) for $H$. bifasciatus and $H$. eques was higher than $H$. anisitsi. The larger size of sexual maturity estimated for $H$. anisitsi is in accordance with their higher fecundity and, in opposition, the smaller size of sexual maturity estimated for $H$. bifasciatus and $H$. eques agrees with their smaller fecundity. Hence, we suggest that the higher reproductive effort of $H$. bifasciatus and $H$. eques is also a response to the flood seasonality in the oxbow lakes that limit the extension of favorable conditions for reproduction.

Environmental conditions may either impose constraints on certain life-history traits or increase the fitness of a species, depending on how their feeding and reproductive habits interact to determine its persistence and abundance (Matthews, 1998). According to Godinho et al. (2010), lentic habitats allow a greater diversity of reproductive styles to fishes than lotic environments. Furthermore, fishes inhabiting similar habitats may have different lifehistory traits, and even closely related species can exhibit different life-history patterns (Wootton, 1992). The life-history traits analyzed in the present study were essential to the comprehension of how species are favored in environments they inhabit depending on their reproductive strategies. Similar responses in those traits may be common to other characid fishes inhabiting similar environments.

\section{Acknowledgements}

We are grateful to Dr. Francisco Langeani for fish identification, Campininha's staff support, IBAMA (02027.000991/2005-71) and COTEC (42.042/2005) for licenses, Dr. Mauricio Cetra for helpful comments, CAPES to the graduate scholarship given to the senior author, and Dr. Fernando Pelicice for comments on earlier versions of the manuscript.

\section{References}

AGOSTINHO AA., MIRANDA, LE., BINI, LM., GOMES, LC., THOMAZ, SM. and SUZUKI, HI. 1999. Patterns of colonization in Neotropical reservoirs and prognosis: aging. In TUNDISI, JG. and STRASKRABA, M. (Eds). Theoretical Reservoir Ecology and its Applications. São Carlos: Instituto Internacional de Ecologia. 892 p.

AGOSTINHO, AA. and JÚlIO JUNIOR, HF. 1999. Peixes da bacia do alto rio Paraná. In LOWEMCCONNEL, RH. (Ed.). Estudos ecológicos em comunidades de peixes tropicais. São Paulo: EdUSP. $534 \mathrm{p}$.

AGOSTINHO, AA., PELICICE, FM. and GOMES, LC. 2008. Dams and fish fauna of the Neotropical region: impacts and management related to diversity and fisheries. Brazilian Journal of Biology, vol. 68, no. 4, p. 1119-1132. PMid:19197482. http://dx.doi. org/10.1590/S1519-69842008000500019

BRANDIMARTE, AL., ANAYA, M., SHIMIZU, GY., MEIRELLES, ST. and CANEPPELE, D. 2008. Impact of damming the Mogi-Guaçu River (São Paulo State, Brazil) on reservoir limnological variables. Lakes \& Reservoirs: Research and Management, vol. 13, no. 1, p. 23-35. http://dx.doi.org/10.1111/j.14401770.2007.00359.x

BUCKUP, PA., MENEZES, NA. and GHAZZI, MS. 2007. Catálogo das espécies de peixes de água doce do Brasil. Rio de Janeiro: Museu Nacional. 195 p.

CETRA, M. 2005. Avaliação do bem estar em peixes: ANCOVA uma alternativa para estudos da relação 
peso-comprimento. Boletim da Sociedade Brasileira de Ictiologia, vol. 81, p. 3-5.

DUGAN, PJ., BARLOW, C., AGOSTINHO, AA., BARAN, E., CADA, GF., CHEN, D., COWX, IG., FERGUSON, JW., JUTAGATE, T., MALLEN-COOPER, M., MARMULLA, G., NESTLER, J., PETRERE, M., WELCOMME, RL., WINEMILLER, KO. 2010. Fish migration, dams, and loss of ecosystem services in the Mekong basin. Ambio, vol. 39, p. 344-348. PMid:20799685 PMCid:PMC3357701. http://dx.doi.org/10.1007/ s13280-010-0036-1

GODINHO, AL., LAMAS, IR. and GODINHO, HP. 2010. Reproductive ecology of Brazilian freshwater fishes. Environmental Biology of Fishes, vol. 87, no. 2, p. 143-162. http://dx.doi.org/10.1007/s10641-0099574-4

GONÇALVES, CS. and BRAGA, FMS. 2008. Diversidade e ocorrência de peixes na área de influência da UHE Mogi Guaçu e lagoas marginais, bacia do alto rio Paraná, São Paulo, Brasil. Biota Neotropica, vol. 8, no. 2, p. 103-114.

JUNK, WJ., BAYLEY, PB. and SPARKS, RE. 1989. The flood pulse concept in river-floodplain systems. Canadian Special Publications of Fisheries and Aquatic Sciences, vol. 106, p. 110-127.

LÉVÊQUE, C., OBERDORFF, T., PAUGY, D., STIASSNY, MLJ. and TEDESCO, PA. 2008. Global diversity of fish (Pisces) in freshwater. Hydrobiologia, vol. 595, no. 1, p. 545-567. http:// dx.doi.org/10.1007/s10750-007-9034-0

LIMA, FCT. and MOREIRA CR. 2003. Three new species of Hyphessobrycon (Characiformes: Characidae) from the upper rio Araguaia basin in Brazil. Neotropical Ichthyology, vol. 1, no 1, p. 21-33. http://dx.doi. org/10.1590/S1679-62252003000100003

MATTHEWS, WJ. 1998. Patterns in freshwater fish ecology. Massachusetts: Kluwer Academic Publisher. $756 \mathrm{p}$.

MESCHIATTI, AJ. and ARCIFA, MS. 2009. A review on the fishfauna of Mogi-Guaçu river basin: a century of studies. Acta Limnologica Brasiliensia, vol. 21, no. 1, p. 135-159.

OLDEN, JD. and KENNARD, MJ. 2010. Intercontinental comparison of fish life history strategies along a gradients of hydrologic variability. American Fisheries Society Symposium, vol. 73, p. 3-107.

PETESSE, ML., PETRERE JR, M. and SPIGOLON, RJ. 2007. Adaptation of the Reservoir Fish Assemblage Index (RFAI) for assessing the Barra Bonita Reservoir (São Paulo, Brazil). River Research and Applications, vol. 23, no. 6, p. 595-612. http://dx.doi. org/10.1002/rra.1001
R DEVELOPMENT CORE TEAM. 2013. $R$ : $A$ language and environment for statistical computing. Vienna: R Foundation for Statistical Computing. Available from: <http://www.R-project.org>.

TEDESCO, PA., HUGUENY, B., OBERDORFF, T., DURR, HH. and MERIGOUX S DE MERONA, B. 2008. River hydrological seasonality influences life history strategies of tropical riverine fishes. Oecologia, vol. 156, no. 3, p. 691-702. PMid:18368426. http:// dx.doi.org/10.1007/s00442-008-1021-2

VAZZOLER, AEAM. 1996. Biologia da reprodução de peixes teleósteos: teoria e prática. Maringá: EDUEM. $169 \mathrm{p}$.

VILA-GISPERT, A., MORENO-AMICH, R. and GARCIA-BERTHOU, E. 2002. Gradients of life-history variation: an intercontinental comparison of fishes. Reviews in Fish Biology and Fisheries, vol. 12, no. 4, p. 417-427. http://dx.doi. org/10.1023/A:1025352026974

WALTER, H. and LIETH, H. 1960. KlimadiagrammWeltatlas. VEB Gustav Fischer Verlag Jena.

WELCOMME, RL., WINEMILLER, KO. and COWX, IG. 2006. Fish environmental guilds as a tool for assessment of ecological conditions of rivers. River Research and Applications, vol. 22, no. 3, p. 377-396. http://dx.doi.org/10.1002/rra.914

WINEMILLER, KO. 1989. Patterns of variation in life history among South American fishes in seasonal environments. Oecologia, vol. 81, no. 2, p. 225-241.

WINEMILLER, KO. 1992. Life-history strategies and the effectiveness of sexual selection. Oikos, vol. 63, no. 2, p. 318-327. http://dx.doi.org/10.2307/3545395

WINEMILLER, KO. 2005. Life history strategies, population regulation, and implications for fisheries management. Canadian Journal of Fisheries and Aquatic Sciences, vol. 62, no. 4, p. 872-885. http:// dx.doi.org/10.1139/f05-040

WINEMILLER, KO. and ROSE, KA. 1992. Patterns of life-history diversification in North American fishes: implications for population regulation. Canadian Journal of Fisheries and Aquatic Sciences, vol. 49, no. 10, p. 2196-2218. http://dx.doi.org/10.1139/ f92-242

WOOTTON, RJ. 1992. Fish ecology. New York: Chapman and Hall. 212 p.

ZAR, JH. 2010. Biostatistical analysis. New Jersey: Prentice-Hall. 944 p.

ZEUG, SC. and WINEMILLER, KO. 2007. Ecological correlates of fish reproductive activity in floodplain rivers: a life-history-based approach. Canadian Journal of Fisheries and Aquatic Sciences, vol. 64, no. 10, p. 1291-1301. http://dx.doi.org/10.1139/ f07-094 